\title{
Growth of the black-lip pearl oyster, Pinctada margaritifera, in suspended culture under hydrobiological conditions of Takapoto lagoon (French Polynesia)
}

\author{
S. Pouvreau ${ }^{a, b, ~}{ }^{*}$, J. Tiapari ${ }^{a}$, A. Gangnery ${ }^{c}$, F. Lagarde ${ }^{a}$, M. Garnier ${ }^{a}$, H. Teissier ${ }^{a}$, G. Haumani ${ }^{d}$, \\ D. Buestel ${ }^{c}$ and A. Bodoy ${ }^{a, b}$
}

a IFREMER-COP, Taravao, Tahiti, French Polynesia

b CREMA, BP 5, 17137 L'Houmeau, France

c IFREMER-PALAVAS, Chemin de Maguelone, 34250 Palavas, France

d SRM, Station de Takapoto, Tuamotu, French Polynesia

*: Corresponding author : Email : spouvrea@ifremer.fr, Tel : 335465094 40, Fax : 33546500600

\begin{abstract}
:
Growth of the black-lip pearl oyster, Pinctada margaritifera var. cumingi, was studied for an annual cycle, from March 1997 to April 1998, in the lagoon of Takapoto atoll (Tuamotu archipelago, French Polynesia). Growth in shell and in tissue were measured every 15 days on three successive age groups of cultivated pearl oysters. At the same time, hydrobiological parameters (temperature, salinity, oxygen concentration, suspended particulate matter), known to have influence on bivalve growth, were followed each week during culture. No seasonal trend was observed in hydrobiological parameters, except for temperature which varied between $26^{\circ} \mathrm{C}$ and $31^{\circ} \mathrm{C}$. The potential food for pearl oysters (particulate organic matter, POM, $\mathrm{mg} \mathrm{I}^{-1}$ ) was slightly concentrated, but always available, so that, in this lagoon environment, no period seemed to be unfavourable to pearl oyster growth. Effectively, growth in shell was regular and shell did not exhibit any annual ring. Nevertheless, as it is often the case for bivalves, shell growth showed a progressive decrease with the age of pearl oyster and followed a classical Von Bertalanffy model: $H=160.5\left(1-\mathrm{e}^{-0.038(t-3.73)}\right)$ with $H$ the shell height (in $\mathrm{mm}$ ) and $t$ the age (in months). On the other side, growth in tissue did not follow the same pattern than for shell: $P$. margaritifera exhibited reduced growth rate in tissue during the warm season (NovemberApril) so that a seasonal growth model was more appropriate: $W_{\text {tissue }}=6.9 /\left(1+e^{(5.58-0.208} t_{t-0.435} \sin (2 \pi / 12\right.$ $\left.{ }_{(t-1.427)}\right)$ with $W_{\text {tissue }}$, the dry tissue weight (in $\mathrm{g}$ ) and $t$ the age (in months). Several results concerning growth rates should be of interest for pearl farming. Firstly, the progressive decrease measured in shell growth rate implies, for pearl seeding operations, that the sooner the nucleus is implanted, the greater is the rate of nacreous deposition on this nucleus, and shorter is the time to obtain a marketable pearl for farmers. Secondly, exhaustive comparison, between growth rates obtained in our study and those obtained in other lagoons, tended to demonstrate that there is a small but significant variability in growth between lagoons of the Tuamotu archipelago. Further investigations need to be engaged in order to determine the most suitable sites for pearl farming in French Polynesia. Finally, comparison between growth of $P$. margaritifera var. cumingi and growth of other pearl oysters showed that $P$. maxima but also $P$. margaritifera var. erythraensis would also exhibit fast growth in Polynesian waters and then, would constitute potential candidates for further Polynesian diversification projects.
\end{abstract}




\section{Abstract}

Growth of the black-lip pearl oysters, Pinctada margaritifera var. cumingi, was studied for an annual cycle, from March 1997 to April 1998, in the lagoon of Takapoto atoll (Tuamotu archipelago - French Polynesia). Growth in shell and in tissue were measured every 15 days on 3 successive age groups of cultivated pearl oysters. In the same time, hydrobiological parameters (temperature, salinity, oxygen concentration, suspended particulate matter), known to have influence on bivalve growth, were followed every weeks around system culture.

No seasonal trend was observed in hydrobiological parameters, except for temperature which varied between $26^{\circ} \mathrm{C}$ and $31{ }^{\circ} \mathrm{C}$. The potential food for pearl oysters (Particulate organic matter, POM, mg l-1) was slightly concentrated, but always available, so that, in this lagoon environment, no period seemed to be unfavourable to pearl oyster growth. Effectively, growth in shell was regular and shell did not exhibit any annual ring. Nevertheless, as it is often the case for bivalves, shell growth showed a progressive decrease with the age of pearl oyster and followed a classical Von Bertalanffy model : $\mathrm{H}=160.5\left(1-\mathrm{e}^{-0.038(\mathrm{t}-3.73)}\right)$ with $\mathrm{H}$ the shell height (in $\mathrm{mm}$ ) and t the age (in months). On the other side, growth in tissue did not follow the same pattern than for shell : P. margaritifera exhibited reduced growth rate in tissue during the warm season (NovemberApril) so that a seasonal growth model was more appropriate $: \mathrm{W}_{\text {tissue }}=6.9 /\left(1+\mathrm{e}^{(5.58-0.208 \mathrm{t}-0.435 \operatorname{Sin}(2 \pi / 12(\mathrm{t}-1.427)}\right)$

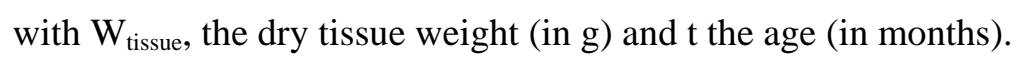

Several results concerning growth rates were of interest for pearl farming. Firstly, the progressive decrease measured in shell growth rate implies, for pearl seeding operations, that the sooner the nucleus is implanted, the greater is the rate of nacreous deposition on this nucleus, and shorter is the time to obtain a marketable pearl for farmers. Secondly, exhaustive comparison, between growth rates obtained in our study and those obtained in other lagoons, tended to demonstrate that there is a small but significant variability in growth between lagoons of the Tuamotu archipelago. Further investigations need to be engaged in order to determine the most suitable sites for pearl farming in French Polynesia. Finally, comparison between growth of P. margaritifera var. cumingi and growth of other pearl oysters showed that P. maxima but also $P$. margaritifera var. erythraensis would also exhibit fast growth in Polynesian waters and then, would constitute potential candidates for further Polynesian diversification projects.

Key Words : Pinctada margaritifera-Growth-Tropical lagoon-Length-weight relations ship-Biochemical composition - Matter in suspension-Pearl Culture. 


\section{INTRODUCTION}

The black-lip pearl oyster, Pinctada margaritifera (Linnaeus, 1758) var. cumingi (Reeve), occurs throughout in the Indo-Pacific region but is abundant in the atoll lagoons of the French Polynesia where it is cultivated for its lucrative black pearls. The culture technique, which showed great variations during the last 20 years, is now stable (subsurface long-line systems) and as follows : spat settles onto artificial materials placed into the lagoon (spat collectors) and are left on the collectors for up to six months. Then, they are transferred on various ongrowing systems (lantern nets or downlines). Pearl-seeding operations begin at about 2 years of age, and pearl is produced approx. 18 months after implantation. After pearl collecting, oysters are sometimes re-implanted to produce a second pearl.

Up to now, density of cultivated pearl oysters has increased dramatically in several atoll lagoon. An important research program (PGRN) is underway to determine the carrying capacity (see review from Héral et al., 1989; Grant et al., 1993; Kashiwai, 1995) of atoll lagoons. In order to reach this aim, a first step is to build a physiological model which explains growth of pearl oyster according to its environment. These kinds of models have already been achieved for other species (Ross and Nisbet, 1990; Bacher et al., 1991; Schneider, 1992; Willows, 1992; Raillard et al., 1993; Van Haren and Kooijman, 1993; Barillé et al., 1997) but nothing is available for $P$. margaritifera in its lagoon environment. In order to build an in situ physiological model of growth, the entire feeding process rates have to be studied on P. margaritifera, preferentially on field experiments (see Robert et al., 1998; Pouvreau et al., 1999a, 1999b). Once the model is built, growth data are required to test the adequacy and reliability of the model.

Moreover, studying growth is of interest for pearl farming, since (1) flesh growth rates constitute useful indicators for pearl oyster health and suitability of the environment as they represent the integrated response of the entire physiological activity of the organisms ; and (2) shell growth rates would give precious information on pearl growth since shell increment and deposition of nacreous matter on the implanted nucleus are strongly correlated (Coeroli and Mizuno, 1985).

Growth rates in bivalve can be estimated by several combined methods : (1) analysis of size-classes in the population; (2) observation of growth rings; (3) measurement of marked individuals; and (4) successive sampling in several known and aged cohorts. Using at less one of these methods, growth rates have been measured in numerous populations of marine bivalves in temperate areas (e.g. Mason, 1957; Mann, 1979; Bayne and Worall, 1980; Richardson et al., 1982; Rodhouse et al., 1984; Thompson, 1984; MacDonald and 
Thompson, 1985; Hilbish, 1986), but growth data are less frequent for tropical or sub-tropical areas (Chellam, 1978; Velez and Epifanio, 1981; Del Rio-Portilla et al., 1992; Numaguchi, 1994; Saucedo and Monteforte, 1997; Taylor et al., 1998).

More precisely, concerning $P$. margaritifera, growth rates are poorly documented. Some measurements on $P$. margaritifera var. erythraensis had been realised in the past, respectively in the Red Sea (Elnaeim, 1984; Nasr, 1984) and in India (Chellam, 1978, 1988) and, concerning P. margaritifera var. cumingi, some data are available for the Cook Islands (Sims, 1993, 1994) and for Polynesian waters (Coeroli et al., 1984; Buestel et al., 1995; Leduc, 1997). But, generally speaking, these studies deal only with growth in shell or concern only a single age group. Furthermore, in these works, data concerning hydrobiology are rarely supplied simultaneously.

To complete this lack of knowledge, our present work estimates in situ growth in shell and in flesh of 3 agegroups of pearl oysters cultivated in the lagoon of Takapoto Atoll (Tuamotu Island - French Polynesia) in relation to hydrobiological conditions and over a year period (1997-1998). This work gives also the first empirical growth models for $P$. margaritifera in French Polynesia. Reproduction of $P$. margaritifera is not described in the present work, but constitutes the subject of a further publication. 


\section{MATERIALS AND METHODS}

\subsection{Study site and environmental parameters}

Growth of cultivated pearl oysters was studied in Takapoto lagoon. Takapoto atoll is located in the Tuamotu Island of French Polynesia. This atoll (Latitude 14³0' S and longitude $145^{\circ} 20^{\prime}$ W) is $18.7 \mathrm{~km}$ long and $4.4 \mathrm{~km}$ wide, and presents an area of $81.7 \mathrm{~km}^{2}$. Mean depth of the lagoon is $23 \mathrm{~m}$, with a maximum at $55 \mathrm{~m}$. Volume of waters is estimated between $1.3 \mathrm{~km}^{3}$ (Sournia and Ricard, 1976) and $2.3 \mathrm{~km}^{3}$ (Yann Morel, pers. comm.). Exchanges with the ocean are very restricted because of the absence of channel into the coral ring. Homogeneity in the body water is ensured by regular trade winds. Sometimes, calm conditions may occur, especially during warm season (November to April), causing occasional development of stratification.

Total Particulate Matter $>1 \mu \mathrm{m}$ (TPM, mg l-1) are rather low (Buestel and Pouvreau, 2000), especially its organic part (POM, mg $\mathrm{l}^{-1}$ ) which constitutes the potential food for pearl oyster. These authors showed that if spatial variations of these parameters are not important in the lagoon, temporal variations are predominant. In order to estimate accurately the range and the source of its variations, TPM was followed every week during one year, from March 1997 to April 1998, at station 1 (Fig. 1) where experimental long-lines were installed. Characteristics of weather (especially air temperature and wind in velocity and in direction) were also monitored in the same time by the Meteo-France meteorological station of Takaroa (atoll close from Takapoto). Physical parameters (temperature, salinity and $0_{2}$ concentration) of water were also recorded by the SRM Takapoto field laboratory with the help of an HYDROLAB multi-parameters probe.

Water for suspended particulate matter (triplicate of $5 \mathrm{l}$ ) was pumped once in a week at the same hour (14 h), pre-filtered at $200 \mu \mathrm{m}$, collected in dark bottle and brought back to the laboratory as fast as possible. Seston were collected by filtration on pre-combusted $\left(500^{\circ} \mathrm{C}\right.$ for $4 \mathrm{~h}$ ) and pre-weighed $47 \mathrm{~mm}$ Whatman GF/C filters. After copiously rinsing with isotonic ammonium formate in order to remove salt, filters were dried overnight at $60{ }^{\circ} \mathrm{C}$ and weighed to give the total particulate matter retained on the filter (TPM in mg dry wt $\mathrm{l}^{-}$ ${ }^{1}$ ). The weight of ash remaining after $4 \mathrm{~h}$ of combustion at $500^{\circ} \mathrm{C}$ gave the value of mineral matter (PIM in mg ash dry wt liter ${ }^{-1}$ ) and losses by ignition gave the organic matter (POM in mg ash free dry wt $\mathrm{l}^{-1}$ ).

\subsection{Growth measurement}

\section{Biological material :}


Growth rates were estimated by sacrificial sampling of pearl oysters in a known population, cultivated at a single station (station 1) in the SW extremity of Takapoto lagoon (see Fig. 1). Farming of these pearl oysters was conducted by the SRM field laboratory. Cultivation technique was very close from those commonly used in professional farms. Suspended long-lines were immersed at $7 \mathrm{~m}$ deep. Pearl oysters were "ear hanging" on downline at low density $\left(<20\right.$ oysters $\mathrm{m}^{-3}$ ) except for young oysters (age group 1$)$ which were arranged in lantern nets where density was somewhat higher. Growth was followed for one year (from March 1997 to April 1998) on three age groups (pseudo-cohorts) : 1, 2 and 3 year-old at the beginning of the study. The age groups were estimated based on the last summer spat fall. Error in estimation was \pm 2 months based on uncertainty in time of spat settlement.

\section{Sampling scheme :}

A systematic sampling scheme was conducted : every 15 days and during 1 year, 40 individuals were randomly sampled in each age group, cleaned of the fouling organisms and sent by aircraft to Tahiti island for measurement, weighing and dissection.

\section{Biometry (see Table 1):}

Concerning the shell, measurements were made according to Hynd (1955). Dry shell weight (both valves) was obtained after drying at $60^{\circ} \mathrm{C}$ for $72 \mathrm{~h}$. Growth striations, which appear on cleaned shells, were also counted, because an interesting relationship with the age was suspected. This counting was realised every 4 months on a sub-sample in each pearl oysters age group. If growth striations can be easily counted on young cleaned shells, a problem occurred for larger oysters because shells were often worn in the vicinity of the umbo. In this case, we designated an area where counting was impossible and we used, as substitute for this area, the average counting of an equivalent area realised on younger pearl oysters, assuming that inter-annual variations were insignificant.

Concerning the flesh, total wet tissue weight (after 5 min of draining) and total dry tissue weight (after a complete freeze-drying cycle) were measured on each individual. After dissection, the same operation was conducted, separately, on adductor muscle, retractor muscle, gills (+mantle) and gonad (+digestive gland). Tissue water content was determined by difference between wet and dry weights and ash content was obtained on a sub-sample ( $\mathrm{n}=10)$ every 15 days after ignition in a muffle furnace at $500{ }^{\circ} \mathrm{C}$ during $12 \mathrm{~h}$. 


\subsection{Statistical analyses}

Three kinds of statistical analyses were performed : (1) estimation of several useful length-weight relationships ; (2) calculation of tissue and shell growth rates and (3) fitting of empirical growth models.

Length-weight relationships were estimated according to the equation $\mathrm{Y}=\mathrm{aX}$. These relationships are very useful to compare data from different studies. Absolute growth rates, i.e. the cumulative increase with respect to time, were calculated as the slope of the regression of growth data vs time, assuming that growth was nearly linear for short period.

Cumulating all the data from the three age-groups, growth in both shell and tissue was expressed as a function of age, determined with empirical growth models fitted on height and weight. To reach this aim, four kinds of models were used : (1) annual shell growth in length was described by the Von Bertalanffy model (1938), already applied on growth curves in Pinctada genus : $\mathrm{Y}=\mathrm{Y}_{\infty}\left[1-\mathrm{e}^{-\mathrm{k}(\mathrm{t}-\mathrm{t})} \mathrm{o}\right]=\mathrm{Y}_{\infty}\left[1-\mathrm{e}^{(\mathrm{a}-\mathrm{kt})}\right]$;

(2) annual shell / tissue growth in weight was directly derived from the previous equation by using the extended Von Bertalanffy model (Richards, 1959) : Y $=\mathrm{Y}_{\infty}\left[1-\mathrm{e}^{-\mathrm{k}(\mathrm{t}-\mathrm{t})}\right]^{\mathrm{b}}$;

(3) results of the extended Von Bertalanffy model were compared with results obtained by a logistic model, which is a derivation of the general model proposed by Schnute and Richards (1990) : Y = $\mathrm{Y}_{\infty} /\left[1-\mathrm{e}^{(\mathrm{a}-\mathrm{kt})}\right]$;

(4) seasonal variations observed in tissue weight were described by incorporating oscillation (e.g. Buestel and Laurec, 1976; Pauly and Gaschütz, 1979; Bodoy, 1982; Buestel et al., 1987) into the previous logistic model, as follows : $\mathrm{Y}=\mathrm{Y}_{\infty} /\left[1-\mathrm{e}^{(\mathrm{a}-\mathrm{kt}-\alpha \sin \omega(\mathrm{t}-\varphi))}\right]$

In these equations, $Y$ represents the height or the weight at time t, $Y_{\infty}$ the asymptotic (or theoretical maximum) length or weight, $t$ the age in months, $k$ the rate at which asymptotic value is approached, $b$ the exponent value from the shell length-weight relationship, $\alpha$ the amplitude of the oscillation, $\varphi$ phase displacement which permit to locate the annual slowing down in growth $(\omega=2 \pi / 12$ when $t$ is expressed in month), $t_{0}$ and $a$ are adjustment parameters without any biological meanings.

These models were fitted by the Marquardt algorithm within Statgraphic's plus Software. Von Bertalanffy model was used in our work in order to permit comparison with other previous works (e.g. Sims, 1994); however, extended models (Schnute and Richards, 1990) are, as a general case, more appropriate (Roff, 1980). 


\section{RESULTS}

\subsection{Environmental parameters}

Long time data sets of water parameters (temperature, salinity and oxygen concentration, POM and PIM, Fig. 2) showed that annual variations were nearly insignificant except for water temperature, which followed a clear seasonal pattern, between $26{ }^{\circ} \mathrm{C}$ in August and $31{ }^{\circ} \mathrm{C}$ in March, strongly linked with the air temperature (Fig. 2a). Salinity varied from 38 to 42 \%o with a hazy seasonal pattern. Oxygen concentration was fairly constant around $6 \mathrm{ml} \mathrm{l}^{-1}$ (Fig. 2b). Mineral and organic particulate matter (PIM and POM, mg $\mathrm{l}^{-1}$; Fig. 2c and Fig. 2d) varied between 0.20 and $0.90 \mathrm{mg} \mathrm{l}^{-1}$ with a turbulent pattern strongly related to wind speed variations, especially for PIM (Fig. 2c).

\subsection{Biometry and length-weight relationships}

Biometry relationships were described by several regressions (Table 2). As a general case, coefficients of determination $\left(\mathrm{R}^{2}\right)$ were very high, indicating that model fitting was highly significant.

Concerning shell measurements, the power exponent of each equation was very close to 1.00 demonstrating that growth in length, in breadth and in thickness was fairly isometric. The nacreous height $\left(\mathrm{H}_{\text {nac }}\right)$ and breadth $\left(\mathrm{B}_{\text {nac }}\right)$ represented, respectively, $75 \%$ and $78 \%$ of the total height $\mathrm{H}\left(\mathrm{H}_{\text {nac }}=0.75 \mathrm{H}\right.$ and $\left.\mathrm{B}_{\text {nac }}=0.78 \mathrm{H}\right)$. The length-weight relationships showed that dry shell weight $\left(\mathrm{W}_{\text {shell }}\right)$ scaled with (height dimensions) ${ }^{3}$, whereas dry tissue weight $\left(\mathrm{W}_{\text {Tissue }}\right)$ scaled with (height dimensions) ${ }^{2.78}$. Organ measurements showed that tissue growth was nearly isometric with power exponent between 0.85 and 1.10 , except for retractor muscle (exponent $b$-values equals to 0.60). Dry shell weight was nearly 24 times greater than dry tissue weight. The relative contribution of each organ to the entire tissue weight was roughly equal to $46 \%$ for muscle, $32 \%$ for gill (+mantle) and $21 \%$ for gonad (+ digestive gland).

The shell increment (S) showed a very regular increase with the pearl oyster age, described by a linear regression (Table 2). The slope $a$ was equal to 1.18 ( $\pm 0.036 \mathrm{SE}$ ) striations by months, i.e. one striation increment every 26 days. The intercept $b$ was significantly different from 0 ( $b=16.58 \pm 1.13 \mathrm{SE}$ ) which shows that striations increment would be higher during the first year of the pearl oyster life cycle. Thus, striations counting appeared to be a reliable method to determine the age for a given pearl oyster : Age (in months) was roughly equal to (S-16.58)/1.18, except for very young oyster ( $<1$ year-old). 


\subsection{Growth rates}

\section{Shell growth :}

As a general case, no seasonal trend was observed in shell growth (Fig. 3). Table 3 showed that, from March 1997 to April 1998, height (H) increased steadily from 44.0 to $76.5 \mathrm{~mm}$ for age group 1, from 97.6 to 113.3 $\mathrm{mm}$ for age group 2 and from 117.1 to 126.8 for age group 3 . Since seasonal trend was insignificant, the daily mean increment in shell height, equal to $95 \mu \mathrm{m} \mathrm{d}^{-1}$ for age group $1,34 \mu \mathrm{m} \mathrm{d}^{-1}$ for age group 2 and 24 $\mu \mathrm{m} \mathrm{d}^{-1}$ for age group 3 (Table 4), showed that shell increment decreased with the age of the pearl oyster. The same observation is also valuable for shell thickness $(\mathrm{T})$ : the nacreous deposition was around $7.2 \mu \mathrm{m} \mathrm{d}^{-1}$ for age group 1 and decreased to $3.1 \mu \mathrm{m} \mathrm{d}^{-1}$ for age group 3 (Table 4). On the other hand, pattern followed by dry shell weight $\left(\mathrm{W}_{\text {Shell }}\right)$ was quite different : increments in shell weight were higher in older oysters (from $109 \mathrm{mg} \mathrm{d}^{-1}$ for age group 1 to $175 \mathrm{mg} \mathrm{d}^{-1}$ for age group 3, Table 4).

\section{Tissue growth :}

Tissue growth showed a different pattern than shell growth. Firstly, tissue growth exhibited a seasonal trend (Table 3) : maximal rate was observed during fresh season (from May to November 97), whereas growth was insignificant during warm season (from December 97 to March 98). In this case, estimation of a mean daily increment in tissue weight becomes less accurate. Secondly, tissue was affected by numerous temporal shortscales variations, especially in the age groups 2 and 3. These variations were mainly observed on gonad compartment, especially in $>2$ year-old pearl oysters (Fig. 3).

\subsection{Empirical growth models}

In order to explain growth in relation with the pearl oyster age, several models were estimated. As a general case, it appeared that the Von Bertalanffy equation described accurately shell growth in length, whereas the logistic form provided better fits for shell and tissue growth in weight.

\section{Shell growth :}

The Von Bertalanffy equation, fitted to shell height data (Fig. 3a), was the following :

$$
\mathrm{H}=160.5\left(1-\mathrm{e}^{-0.038}(\mathrm{t}-3.73)\right) \text { with } \mathrm{R}^{2}=0.96
$$

This model provided an estimate of the asymptotic height $\mathrm{H}_{\infty}$ and an estimate of the growth parameter $\mathrm{k} . \mathrm{H}_{\infty}$ was found to be equal to $160.5 \mathrm{~mm}( \pm 6.6 \mathrm{SE})$, whereas $\mathrm{k}$ was equal to 0.038 month $^{-1}( \pm 0.004 \mathrm{SE})$. The $\mathrm{t}_{0}$ 
value was found to be 3.73 months ( $\pm 0.66 \mathrm{SE}$ ). Nevertheless, fitting was not good for young oysters and a logistic model would be more appropriate (Fig. 3a). The equation became the following :

$$
\mathrm{H}=129.2 /\left(1+\mathrm{e}^{(2.31-0.127 \mathrm{t})}\right) \text { with } \mathrm{R}^{2}=0.97
$$

Adequacy between model and observations was better than previously $\left(\mathrm{R}^{2}=0.97\right)$ especially for young oyster. The asymptotic value for shell height, $\mathrm{H}_{\infty}$, became lower : $129.2 \mathrm{~mm}( \pm 4.3 \mathrm{SE})$.

The extended Von Bertalanffy equation was applied to shell weight data, by using the exponent value of the shell length-weight relationship ( $b=3$, see Table 2). The equation, described on Fig. 3b, became :

$$
\mathrm{W}_{\text {shell }}=292.5\left(1-\mathrm{e}^{-0.06(\mathrm{t}-8.73)}\right)^{3} \text { with } \mathrm{R}^{2}=0.99
$$

The theoretical asymptotic mean value for shell weight, $\mathrm{W}_{\text {shell } \infty}$, was equal to $292.5 \mathrm{~g}$ ( $\pm 12.0 \mathrm{SE}$ ), the growth parameter $\mathrm{k}$ was equal to 0.061 month $^{-1}\left( \pm 0.004 \mathrm{SE}\right.$ ) and the adjustment parameter, $\mathrm{t}_{0}$, was equal to 8.73 months ( \pm 0.66 SE). As previously, a logistic curve exhibited a better adjustment (Fig. 3b), especially for young individuals, and the new equation was :

$$
\mathrm{W}_{\text {shell }}=241.7 /\left(1+\mathrm{e}^{(2.10-0.110 \mathrm{t})}\right) \text { with } \mathrm{R}^{2}=0.98 \text {. }
$$

The asymptotic value for shell weight became lower : $241.7 \mathrm{~g}$ ( $\pm 6.3 \mathrm{SE}$ ).

\section{Tissue growth :}

As previously, data suggest a sigmoïdal form, so that logistic model would provide an accurate fit. Preliminary results given by fitting the extended Von Bertalanffy model are summarised in the following equation (see Fig. 3c) :

$$
\mathrm{W}_{\text {tissue }}=13.9\left(1-\mathrm{e}^{-0.038(\mathrm{t}-3.919)}\right)^{2.78} \text { with } \mathrm{R}^{2}=0.95
$$

The theoretical mean value for tissue weight, $\mathrm{W}_{\text {Tissues, }}$, was equal to $13.9 \mathrm{~g}$ ( $\left.\pm 0.6 \mathrm{SE}\right), \mathrm{k}=0.038$ month $^{-1}$ ( $\pm 0.004 \mathrm{SE})$ and $\mathrm{t}_{0}=3.92$ months $( \pm 0.75 \mathrm{SE})$. Model adequacy was not satisfactory, especially for old oysters ; in that $\mathrm{W}_{\text {Tissue } \infty}$ was over-estimated. Since data showed repetitive seasonal oscillations, a more complete model incorporating seasonal effect was preferable. Then, the equation became (see Fig. 3c) :

$$
\mathrm{W}_{\text {tissue }}=6.9 /\left(1+\mathrm{e}^{(5.58-0.208 \mathrm{t}-0.435 \operatorname{Sin}(2 \pi / 12(\mathrm{t}-1.427)}\right) \text { with } \mathrm{R}^{2}=0.98
$$

This new model exhibited a very good fitting with the data. In that case, asymptotic value $\mathrm{W}_{\text {tissue } \infty}$ was $6.9 \mathrm{~g}$ ( $\pm 0.1 \mathrm{SE})$. Rate at which this asymptotic value is approached was equal to $0.208 \mathrm{month}^{-1}( \pm 0.010 \mathrm{SE})$ and 
$\alpha$, a measure of the oscillation amplitude, was equal to $0.435 \mathrm{~g}$ ( $\pm 0.061 \mathrm{SE}$ ). Phase displacement averaged 1.427 month $( \pm 0.239 \mathrm{SE})$. Adequacy between observations and predictions was good $\left(\mathrm{R}^{2}=0.98\right)$.

Individual organ growth followed similar patterns and the same kind of model was applied. Parameter estimates of all these models are given in Table 5. Models for adductor muscle and gill exhibited a high reliability ( $\mathrm{R}^{2} \sim 0.98$, Fig. 3d and Fig. 3e). Gonad (+digestive gland) showed numerous small-scale variations (Fig. 3f) which affected adequacy between data and model, as indicated by larger SE and lower $\mathrm{R}^{2}$ values (Table 5). Asymptotic values for adductor muscle, retractor muscle, gill and gonad were, respectively, equal to $2.84,0.42,2.00$ and $1.39 \mathrm{~g}$. The sum of this 4 asymptotic values was in total agreement with $\mathrm{W}_{\text {Tissues }}$ obtained previously. 


\section{Discussion}

\subsection{Lagoon environment variability}

Polynesian lagoon water, and especially Takapoto lagoon, are characterised by very low POM and PIM concentrations in comparison with other shellfish areas where bivalve food resources have been examined. In Polynesian water, POM was well-studied concerning its taxinomic composition (e.g. Charpy, 1996; Charpy et al., 1997 ; Charpy and Blanchot, 1998), whereas less is known about its annual variation. This work showed that POM is available all around the year. Thus, no period of starvation occurs in pearl oyster populations. Temperature was the only one parameter to show seasonal variations. But amplitude of these variations was low $\left(<5^{\circ} \mathrm{C}\right)$ and minimal value (reached in August) was $26{ }^{\circ} \mathrm{C}$, so that this parameter could not constitute an inhibitor factor for growth, as it is the case in temperate environments. Since oxygen concentration and salinity were also very constant, no season is unfavourable to pearl oyster growth. Lagoon environment stability would imply regular growth of pearl oyster.

\subsection{Pearl oyster growth}

The growth of a bivalve is the total result of many interacting endogenous and exogenous factors. Among endogenous factors, age is presumably the most important. Among exogenous factors, we can distinct those which are related to environment (food supply and temperature) and those which are related to farming conditions (density, depth, trophic competitors).

\section{Endogenous factors}

Growth rates in shell or tissue are directly related to bivalve age. Growth in P. margaritifera was fast up to the third year and thereafter it became reduced. Most of the studies (e.g. Nalluchinnappan et al., 1982 ; Nasr, 1984 ; Gervis and Sims, 1992 ; Numaguchi, 1994) who investigated pearl oyster growth have lead to the same conclusion. This decrease with age is strongly linked with the progressive investment in reproduction, since the part of the scope for growth which is allocated to reproduction (called the reproductive effort, ER, Thompson, 1984) is lost for shell or tissue growth. 
Among the various parameters of growth presented in this work, those concerning shell thickness and nacreous deposition deserves a special care. Increment in nacreous deposition, which was equal to $7.2 \mu \mathrm{m}$ days $^{-1}$ during the second year of the life cycle (in total agreement with Caseiro, 1993), decreased dramatically with the age of pearl oyster and reached a mean value of $3.1 \mu$ days $^{-1}$ during the fourth year of the life cycle. This result is full of interest for two reasons.

Firstly, for pearl seeding operations and farming management, it implies that the sooner the nucleus is implanted, the greater is the rate of nacreous deposition on this nucleus, and shorter is the time to obtain a marketable pearl for farmers.

Secondly, for biologists, it implies that heel depth (shell thickness) does not constitute a good indicator for age determination as reported by Tranter (1958), Thielley (1993) or Sims (1993, 1994). This work showed effectively that the best non destructive indicator for age determination in P. margaritifera in Polynesian water was presumably the growth striations, since annual growth rings (Pandya, 1976) are not well-defined in P. margaritifera. The increment in striation (approx. 1 month $^{-1}$ for $>1$ year-old pearl oyster) could be related to the monthly periodicity of lunar cycle since in the lagoon environment no other monthly stresses are evident (tide are insignificant and pearl oyster are never emerged). Tagging experiments would confirm this interesting assumption and further works should be performed in that way.

\section{Environmental factors}

Previous studies of growth of Pteriidae in tropical environment (Coeroli et al., 1984; Gervis and Sims, 1992; Sims, 1993 and 1994; Saucedo and Monteforte, 1997) were restricted to study the shell growth (in length or in weight), and observed no seasonal trend. On the contrary, our study showed that seasonal variations occurred, but only in tissue growth : tissue growth slowed in austral summer (warm season), especially for $>2$ year-old pearl oysters (an observation in agreement with Leduc (1997) who measured a decline in tissue weight in 3 year-old pearl oysters inhabiting an other Polynesian lagoon).

Bivalve growth increments are known to be strongly influenced by environmental conditions such as food supply and water temperature (e.g. Thompson, 1984). In our study, the slowing down in growth observed in summer could not be related to food concentration (POM) since this factor remained relatively constant. As a general case, in temperate regions, a rise in temperature is favourable for bivalve growth (e.g. Richardson et al., 1982), but in an environment of low food availability, a rise in temperature which results in an increased 
metabolic energy expenditure may cause a reduction in growth rate (Mann, 1979 ; Bayne and Worall, 1980 ; Sebens, 1982) as it may be the case in our study. For example, working in the Gulf of Kutch, Gokhale et al. (1954) assumed that pearl oysters $P$. fucata grew vigorously in winter months and ceased in summer. This observation was confirmed by Pandya (1976) who reported that growth rate was higher between 19 and $28^{\circ} \mathrm{C}$ than between 28 to $32^{\circ} \mathrm{C}$. Such decreases at higher temperatures has also been shown for other species (e.g. Laing et al., 1987 ; del Rio-portilla et al., 1992). In that respect, warm season may constitute a risky period for pearl oysters culture, and a special care must be taken, especially for El niño years.

\section{Farming conditions}

Depth, stocking density and bio-fouling are also known to modify pearl oysters growth (Chellam, 1978; Nasr, 1984; Elnaeim, 1984; Buestel et al., 1995; Leduc, 1997). We tried to maintain control on these three factors : depth was fixed, density was low and pearl oysters were cleaned periodically of bio-fouling.

Bad farming conditions (especially high density) may be the explanation of mortality events. An episode of high mortality was observed in 1985-1986 in several Polynesian lagoons. At this time, P. margaritifera was cultivated on tables at higher densities than are now employed. High density combined with high temperature and low renewal of water may cause significant mortality in culture. Such an explanation have already been used to explain mortality of $P$. fucata in Ohmura Bay in 1976 (Numaguchi, 1994). To give a better understanding, a depletion model (e.g. Fréchette et al., 1989; Incze et al., 1981) is at the present time in construction, and will be the aim of a further paper.

\subsection{Comparison with other species and/or with other area}

Growth data and especially those concerning shell are important for pearl farming since they give useful information concerning (1) pearl oysters health in culture system ; (2) deposition rate of nacreous matter on the shell but also on the implanted nucleus ; and (3) suitability of potential pearl farming sites. In that respect, comparing growth performance, for several pearl oyster species and/or for several areas, is full of interest.

If growth rate in tissue weight are poorly documented for the genus Pinctada (Elnaeim, 1984 ; Leduc, 1997), data concerning shell growth are more abundant (Chellam, 1978; Elnaeim, 1984; Nasr, 1984; Coeroli et al., 
1984; Chellam, 1988; Sims, 1993, 1994; Buestel et al., 1995; Leduc, 1997). Table 6 gives an overview of the existing knowledge concerning shell growth rates in Pteriidae, and permits comparison. Growth rate in $P$. margaritifera was higher than those measured in $P$. fucata or in P. mazatlanica. Unfortunately, no comparable data are available on P. maxima which certainly exhibits the highest growth rate of the Pinctada genus (Gervis and Sims, 1992 ; Yukihira et al., 1998). Concerning P. margaritifera var cumingi, the highest shell growth rate was obtained in Takapoto atoll : the assumption of « dwarfism » of the pearl oyster which inhabit the Takapoto lagoon need certainly to be moderate.

In some cases, Von Bertalanffy model had been applied on the available data (Table 7), and the parameters $\mathrm{H}_{\infty}$ and $k$ of the equation are also useful in comparing intra or interspecific growth performance.

Concerning interspecific performance, the lowest $\mathrm{H}_{\infty}$-value were obtained in P. fucata, in P. mazatlanica and in P. margaritifera var. erythraensis which respectively averaged 79.3, 84.9 and $125.5 \mathrm{~mm}$. On the other side, these three smaller species exhibit faster growth rates (higher $k$-values) and their life expectancy are shorter with a life of only approx. 3-4 years (Gervis and Sims, 1992). The highest $\mathrm{H}_{\infty}$-values may presumably obtained for P. maxima (Yukihira et al., 1998, reported maximum shell height above $200 \mathrm{~mm}$ ) but Von Bertalanffy parameters are not yet available on this species. P. margaritifera var. cumingi showed intermediary $\mathrm{H}_{\infty}$ and $k$-values, respectively around $160 \mathrm{~mm}$ and $0.45 \mathrm{~mm} \mathrm{y}^{-1}$.

Variability in intraspecific performances is also significant, especially for P. margaritifera var. cumingi (Table 7). The $k$-value varied between 0.35 and $0.76 \mathrm{~mm}$ year ${ }^{-1}$ and the $\mathrm{L}_{\infty}$-value between 148.9 and $181.7 \mathrm{~mm}$. The main source of these variations is presumably the pearl farming sites : Sims (1994) worked in Cook Islands, Leduc (1997) in Rangiroa atoll and Coeroli et al. (1984) in Takapoto atoll. In a very recent work, Yukihira et al. (1998) measured maximal length around $150 \mathrm{~mm}$ in Australia waters. This tends to show that P. margaritifera growth is presumably different from an atoll to an other. In that respect, variability in growth between lagoons need to be studied and would certainly bring very useful information concerning (1) the relationships between growth and environmental parameters ; and (2) the most suitable sites for pearl oyster farming. To reach this aim, growth would be studied not only for external parameters (height or striation), but also for internal ones (tissue and maturity). 
Finally, we can conclude that the black-lipped pearl oyster Pinctada margaritifera var. cumingi shows relative fast growth in Polynesian waters, although food suspension (POM) is rather low. This ability to growth fast in poor environment is permitted by high pumping activity (see Pouvreau et al., 1999a and 1999b for P. margaritifera in Polynesian waters). Other Pteriidae have also developed the same ability (see Yukihira et al., 1998) : for example, P. maxima, which typically inhabits area characterised by higher amount of suspended particulate matter than those of $P$. margaritifera, can also exhibit high efficiency to grow under low food suspensions. In that respect, P. maxima and presumably other species as $P$. margaritifera var. erythraensis, may also exhibit fast growth in Polynesian waters and, then, may constitute potential candidates for further Polynesian diversification projects.

\section{Acknowledgements}

This work, entitled "Project CREM", was carried out at the IFREMER Pacific Oceanological Centre (Tahiti) and was supported by the "Programme Général de Recherche sur la Nacre" and by a financial help of the Research Ministry. At the end of this work, we would like to thank all the person from the Tahiti - IFREMER centre and especially S. Robert, G. Jonquières, A. Bennett and X. Caisey for their numerous help during CREM project. We want also to thank all the SRM team for their field assistance on Takapoto atoll. 


\section{References}

Bacher, C., Héral, M., Deslous-Paoli, J.M., Razet, D., 1991. Modèle énergétique uniboite de la croissance des huîtres (Crassostrea gigas) dans le bassin de Marennes-Oléron. Can. J. Fish. Aquat. Sci. 48, 391-404.

Barillé, L., Héral, M., Barillé-Boyer, A.L., 1997. Modélisation de l'écophysiologie de l’huître creuse Crassostrea gigas dans un environnement estuarien. Aquat. Living Resour. 10, 31-48

Bayne, B.L., Worall, C.M., 1980. Growth and production of mussels Mytilus edulis from two populations. Mar. Ecol. Prog. Ser. 3, 317-328.

Bodoy, A., 1982. Croissance saisonnière du bivalve Donax trunculus en Méditerranée Nord-Occidentale (France). Proceeding of the 7th International Malacological Congress, Perpignan (France), 31 Aout-7 Septembre 1980. Malacologia 22 (1-2), 353-358.

Buestel, D., Laurec, A., 1976. Croissance de la coquille Saint-Jacques Pecten maximus en rade de Brest et en Baie de Saint Brieuc. Haliotis 5, 173-177.

Buestel, D., Gérard, A., Guénolé, A., 1987. Croissance de différents lots de coquille Saint-Jacques Pecten maximus en culture sur le fond dans la rade de Brest. Haliotis 16, 463-477.

Buestel D., Pouvreau S., Tiapari J., Bougrier S., Chabirand J.M., Geairon P., Fougerouse A., 1995. Ecophysiologie de l'huître perlière : Approche des relations entre la croissance de l'huitre Pinctada margaritifera et le milieu dans le lagon de Takapoto. IFREMER RIDRV 95 - 18 RA, Tahiti, 79 pp.

Buestel, D., Pouvreau S., 2000. La matière particulaire des eaux du lagon de Takapoto : nourriture potentielle pour les élevages d'huîtres perlières. Oceanologica Acta, in press.

Caseiro, J., 1993. L’huître perlière de Polynésie. Biominéralisation, Paramètres et processus de croissance, effets chromatiques dans la coquille et la perle de Pinctada margaritifera. Th. Univ. Claude BernardLyon I/ France, N²17-93, 171 pp.

Charpy, L., 1996. Phytoplankton biomass and production in two Tuamotu atoll lagoons (French Polynesia). Mar. Ecol. Prog. Ser. 145, 133-142.

Charpy, L., Dufour, P., Garcia, N., 1997. Particulate organic matter in sixteen Tuamotu atoll lagoons (French polynesia). Mar. Ecol. Prog. Ser. 151, 55-65.

Charpy, L., Blanchot, J., 1998. Photosynthetic picoplankton in French Polynesian atoll lagoons : estimation of taxa contribution to biomass and production by flow cytometry. Mar. Ecol. Prog. Ser. 162, 51-70.

Chellam, A., 1978. Growth of pearl oyster Pinctada fucata in the pearl culture farm at Veppalodai. Indian J. Fish., 25, 77-83.

Chellam, A., 1988. Growth and biometric relationship of pearl oyster Pinctada fucata (Gould). Indian J. 
Fish., 35, 1-6

Coeroli, M., De Gaillande, D., Landret, J.P., 1984. Recent innovations in cultivation of molluscs in French Polynesia. Aquaculture 39, 45-67.

Coeroli, M., Mizuno, K., 1985. Study of different factors having an influence upon the pearl production of the black lip pearl oyster. Proc. 5th Int. Coral Reef Symp., Tahiti 5, 551-556.

Del Rio-Portilla, M.A., Re-Araujo, A.D., Voltolina, D., 1992. Growth of the pearl oyster Pteria sterna under different thermic and feeding conditions. Mar. Ecol. Prog. Ser. 89, 221-227.

Elnaeim, A.G., 1984. Variability in growth of the mother of pearl oyster (Pinctada margaritifera) in the Red Sea (Sudan). Th. Dalhousie Univ. 120 pp.

Fréchette, M., Butman, C.A., Geyer, W.R., 1989. The importance of boundary-layer flows in supplying phytoplankton to the benthic suspension feeder Mytilus edulis L. Limnol. Oceanogr. 34, 19-36.

Gaetan-Mondragon, I., Caceres-martinez, C., Tobias-Sanchez, M., 1993. Growth of the pearl oysters Pinctada mazatlanica and Pteria sterna in different culture structures at La Paz Bay, Baja California Sur, Mexico. J. World Aquac. Soc. 24 (4), 541-546.

Garcia, F., 1993. Interprétation des stries valvaires pour l'évaluation de la croissance de Ruditapes decussatus L. Oceanol. Acta 16 (2), 199-203.

Gokhale, S.V., Eswaran, C.R., Narasimhan, R., 1954. Growth rate of the pearl oyster Pinctada pinctada in the Gulf of Kutch with a note on the pearl fishery of 1953. J. Bombay nat. Hist. Soc. 52 (1), 124-136

Gervis, M.H., Sims, N.A., 1992. The biology and culture of pearl oysters (Bivalvia: Pteriidae). Iclarm Stud. Rev. 21, 49 pp.

Grant, J., Dowd, M., Thompson, K., Emerson, C, Hatcher, A., 1993. Perspectives on field studies and related biological models of bivalve growth and carrying capacity. in Bivalves Filter Feeders in Estuarines and Coastal Ecosystems Processes, RF Dame (ed.), NATO ASI Series G33, pp 371-421

Héral, M., Bacher C., Deslous-Paoli, J.M. 1989. La capacité biotique des bassins ostréicoles. in: L’homme et les ressources halieutiques, J.P. Troadec (éd.), IFREMER,. pp 225-259.

Hilbish, J.H., 1986. Growth trajectories of shell and soft tissue in bivalves: seasonal variation in Mytilus edulis L. J. Exp. Mar. Biol. Ecol. 96, 103-113.

Hynd, J.S., 1955. A revision of Australian pearl shells, genus Pinctada. Aust. J. Mar. Freshwat. Res. 6 (1), 98-137.

Incze, L.S., Lutz, R.A., True, E., 1981. Modelling carrying capacities for bivalves molluscs in open, suspended-culture system. J. Word Maricul. Soc. 12 (1), 143-155. 
Kashiwai, M., 1995. History of carrying capacity concept as an index of ecosystem productivity (review). Bull. Hokkaido Natl. Fish. Res. Inst. 59, 81-100

Laing, I., Utting, S.D., Kilada, R.W.S., 1987. Interactive effect of diet and temperature on the growth of juvenile clams. J. Exp. Mar. Biol. Ecol. 113, 23-28.

Leduc, H.T., 1997. Conséquences de quelques techniques d'élevage de la nacre Pinctada margaritifera (Linné, 1758) var. cumingi (Jameson, 1901): mortalité et indice de condition. Diplôme E.P.H.E., Perpignan univ., France, 114 pp.

MacDonald, B.A., Thompson, R.J., 1985. Influence of temperature and food availability on the ecological energetics of the giant scallop Placopecten magellanicus. I. Growth rates of shell and somatic tissue. Mar. Ecol. Prog. Ser. 25, 279-294.

Mann, R., 1979. Some biochemical and physiological aspects of growth and gametogenesis in Crassostrea gigas and Ostrea edulis grown at sustained elevated temperatures. J. mar. biol. Ass. U.K. 59, 95-110.

Mason, J., 1957. The age and growth of the scallop, Pecten maximus (L.), in Manx waters. J. mar. biol. Ass. U.K. 36, 473-492.

Nalluchinnappan, I., Sudhandra dev, D., Irulandi, M., Jeyabaskaran, Y., 1982. Growth of pearl oyster Pinctada fucata (Gould) in cage culture at Kundugal channel, Gulf of Mannar. Indian J. Mar. Sci. 11, 193-194.

Nasr, D.H., 1984. Feeding and growth of the pearl oyster Pinctada margaritifera (L.) in Dongonab Bay, Red Sea. Hydrobiologia 110, 241-245.

Numaguchi, K., 1994. Growth and physiological condition of the japanese pearl oyster, Pinctada fucata martensii (Dunker, 1850) in Ohmura bay, Japan. J. Shellfish Res. 13 (1), 93-94.

Pandya, J.A., 1976. Influence of temperature on growth ring formation in the pearl oyster, Pinctada fucata (Gould) of the Gulf of Kutch. Indian J. Mar. Sci. 5, 249-251.

Pauly, D., Gaschütz, G., 1979. A simple method for fitting oscillating length growth data, with program for pocket calculator. I.C.E.S./C.M. 1979/G 24, 26pp.

Pouvreau, S., Jonquières, G., Buestel, D., 1999a. Filtration by the pearl oyster, Pinctada margaritifera, under conditions of low seston load and small particles size in a tropical lagoon habitat. Aquaculture, 176, 295314.

Pouvreau, S., Bodoy, A., Buestel, D., 1999b. In situ suspension feeding behaviour of the pearl oyster, Pinctada margaritifera: combined effects of body size and weather-related seston composition. Aquaculture, in press.

Raillard, O., Deslous-paoli, J.M., Héral. M., Razet. D., 1993. Modélisation du comportement nutritionnel et 
de la croissance de l’huître japonaise, Crassostrea gigas. Oceanol. Acta 16 (1), $73-82$

Richards, F.J., 1959. A flexible growth function for empirical use. J. Exp. Bot. 10, 290-300.

Richardson, C.A., Taylor, A.C., Venn, T.J., 1982. Growth of the queen scallop Chlamys opercularis in suspended cages in the firth of clyde. J. mar. biol. Ass. U.K. 62, 157-169

Robert, S., Pouvreau, S., Buestel, D., Goulletquer, P., Bennett, A., Caisey, X., Teissier, H., Jonquières, G., Tiapari, J., Haumani, G., 1998. Energy budget of the pearl oyster Pinctada margaritifera: in situ respiration rate assessment and allometry relationship with dry meat weight oyster. Aquaculture Europe 98, 7-10 Octobre 1998, Bordeaux, France. Abstract only.

Rodhouse, P.G., Roden, C.M., Burnell, G.M., Hensey, M.P., McMahon, T., Ottway, B., Ryan, T.H., 1984. Food resource, gametogenesis and growth of Mytilus edulis on the shore and in suspended culture : Killary harbour, Ireland. J. mar. biol. Ass. U.K. 64, 513-529.

Roff, D.A., 1980. A motion for the retirement of the von Bertalanffy Function. Can. J. Fish. Aquat. Sci. 37, 127-129.

Ross, A.H., Nibet, R.M., 1990. Dynamic models of growth and reproduction of the mussel Mytilus edulis L. Functionnal Ecology 4, 777-787

Saucedo, P., Monteforte, M., 1997. In situ growth of pearl oysters Pinctada mazatlanica (Hanley 1856) and Pteria sterna (Gould 1851) under repopulation conditions at Bahia de La Paz, Baja California Sur, Mexico. Aquaculture Res. 28, 367-378.

Schneider, D.W., 1992. A bioenergetics model of zebra mussel, Dreissena polymorpha, growth in the great lakes. Can. J. Fish. Aquat. Sci. 49, 1406-1416.

Schnute, J.T., Richards, L.J., 1990. A unified approach to the analysis of fish growth, maturity, and survivorship data. Can. J. Fish. Aquat. Sci. 47 , 25-40.

Sebens, K.P., 1982. The limits to indeterminate growth : an optimal size model applied to passive suspension feeders. Ecology 63, 209-222.

Sims, N.A., 1993. Size, age and growth of the black-lip pearl oyster, Pinctada margaritifera (L.) (Bivalvia, pteriidae). J. Shellfish Res. 12 (2), 223-228.

Sims, N.A., 1994. Growth of wild and cultured black-lip pearl oysters, Pinctada margaritifera (L.) (Bivalvia, pteriidae). Aquaculture 122, 181-191.

Sournia, A., Ricard, M., 1976. Données sur l'hydrologie et la productivité du lagon d'un atoll fermé (Takapoto îles Tuamotu). Vie Milieu B 26 (2), 243-279.

Taylor, J.J., Southgate, P.C, Rose, R.A., 1998. Effects of mesh covers on the growth and survival of silver- 
lip pearl oyster (Pinctada maxima, Jameson) spat. Aquaculture 162, 241-246.

Thielley, M., 1993. Etude cytologique de la gamétogenèse, de la sex-ratio et du cycle de reproduction chez l'huître perlière Pinctada margaritifera (L) var. cumingii (Jameson), (mollusques, bivalves). Comparaison avec le cycle de Pinctada maculata (Gould). Th. Univ. Tahiti., Polynésie Française, 233 pp.

Thompson, R.J., 1984. Production, reproductive effort, reproductive value and reproductive cost in a population of the blue mussel Mytilus edulis from a subartic environment. Mar. Ecol. Prog. Ser. 16, 249257.

Tranter, D.J., 1958. Reproduction in australian pearl oysters (Lamellibranchia). I. Pinctada albina (Lamarck) : primary gonad development. Aust. J. Mar. Freshw. Res. 9 (1), 135-143.

Van Haren, R.J.F., Kooijman S.A.L.M., 1993. Application of a dynamic energy budget model to Mytilus edulis (L.). Neth. J. Sea Res. 31 (2), 119-133.

Velayudhan, T.S., Chellam, S., Dharmaraj, S., Victor, A.C.C., Kasim, M., 1996. Comparison of growth and shell attributes of four generations of the pearl oyster Pinctada fucata (Gould) produced in the hatchery. Indian J. Fish. 43 (1), 69-77.

Velez, A., Epifanio, C.E., 1981. Effects of temperature and ration on gametogenesis and growth in the tropical mussel Perna perna (L.). Aquaculture 22, 21-26.

Von Bertalanffy, L., 1938. A quantitative theory of organic growth. Hum. Biol., 81: 181-213.

Wada, K.T., 1991. The pearl oyster, Pinctada fucata (Gould) (family Pteriidae). In: Estuarine and marine bivalve culture. Menzel, W. (Ed.), CRC press, Boca Raton, 362 pp.

Willows, R.I., 1992. Optimal digestive investment: A model for filter feeders experiencing variable diets. Limnol. Oceanogr. 37 (4), 829-847.

Yukihira, H., Klumpp, D.W., Lucas, J.S., 1998. Effects of body size on suspension feeding and energy budgets of the pearl oysters Pinctada margaritifera and P. maxima. Mar. Ecol. Prog. Ser. 170,: 119-130. 


\section{Tables}

Table 1 : Parameters, acronyms, and units used in this study for growth measurements on Pinctada margaritifera.

\begin{tabular}{|c|c|c|c|}
\hline Parameters & Acromyms & Measurements & Units \\
\hline \multicolumn{4}{|l|}{ Shell measurements } \\
\hline $\begin{array}{r}\text { Total lenght } \\
\text { (dorso-ventral axis) }\end{array}$ & $\mathrm{L}$ & $\begin{array}{l}\text { From the heel to the furthermost edge of non-nacreous border, excluding digitate } \\
\text { processes and taking into account the curve of the right shell }\end{array}$ & $\mathrm{mm}$ \\
\hline $\begin{array}{r}\text { Total height or diameter } \\
\text { (dorso-ventral axis) }\end{array}$ & $\mathrm{H}$ & $\begin{array}{l}\text { From the heel to the furthermost edge of non-nacreous border, excluding digitate } \\
\text { processes without taking into account the curve of the right shell }\end{array}$ & $\mathrm{mm}$ \\
\hline $\begin{array}{l}\text { Height of nacreous layer } \\
\text { (dorso-ventral axis) }\end{array}$ & $\mathrm{H}_{\text {nac }}$ & $\begin{array}{l}\text { From the heel to the furthermost edge of nacreous border without taking into account } \\
\text { the curve of the right shell }\end{array}$ & $\mathrm{mm}$ \\
\hline $\begin{array}{r}\text { Breath of nacreous layer } \\
\text { (antero-posterior axis) }\end{array}$ & $\mathrm{B}_{\text {nac }}$ & $\begin{array}{l}\text { From the anterior edge of nacreous border to the posterior one parallel to the heel } \\
\text { and without taking into account the curve of the right shell }\end{array}$ & $\mathrm{mm}$ \\
\hline Thickness of shell & $\mathrm{T}$ & Thickness of the valve at the hinge line on dissected valve & $\mathrm{mm}$ \\
\hline External growth striations & $\mathrm{S}$ & Number of concentric lines counted on cleaned shell & \\
\hline Shell weight & $\mathrm{W}_{\text {shell }}$ & Dry shell weight (both valves) obtained after drying at $60^{\circ} \mathrm{C}$ for $72 \mathrm{~h}$ & g \\
\hline \multicolumn{4}{|l|}{ Flesh measurements } \\
\hline Tissue weight & $\mathrm{W}_{\text {tissue }}$ & Dry soft tissue weight obtained after a complete freeze-drying cycle & g \\
\hline Adductor muscle weight & $\mathrm{W}_{\mathrm{mu} 1}$ & Dry weight of adductor muscle obtained after a complete freeze-drying cycle & g \\
\hline Retractor muscle weight & $\mathrm{W}_{\mathrm{mu} 2}$ & Dry weight of retractor muscle obtained after a complete freeze-drying cycle & g \\
\hline Gills weight & $\mathrm{W}_{\text {gill }}$ & Dry weight of gills (+mantle) otained after a complete freeze-drying cycle & g \\
\hline Gonad weight & $\mathrm{W}_{\text {gonad }}$ & Dry weight of gonad (+digestive gland) otained after a complete freeze-drying cycle & g \\
\hline
\end{tabular}


Table 2 : Regression statistics for the biometric parameters measured on pearl oysters in this study.

\begin{tabular}{ccccc}
\hline $\mathrm{Y}$ & $\mathrm{X}$ & Equation & $\mathrm{R}^{2}$ & $p$ \\
\hline \multicolumn{2}{c}{ Shell dimensions } & & & \\
$\mathrm{H}_{\text {nac }}$ & $\mathrm{H}$ & $1.07(+/-0.008 \mathrm{SE}) \mathrm{H}^{0.99(+/-0.001 \mathrm{SE})}$ & 0.99 & 0.0000 \\
$\mathrm{H}_{\text {nac }}$ & $\mathrm{H}$ & $0.75(+/-0.006 \mathrm{SE}) \mathrm{H}^{1.03(+/-0.002 \mathrm{SE})}$ & 0.99 & 0.0000 \\
$\mathrm{~B}_{\text {nac }}$ & $\mathrm{H}$ & $0.78(+/-0.012 \mathrm{SE}) \mathrm{H}^{1.00(+/-0.003 \mathrm{SE})}$ & 0.96 & 0.0000 \\
$\mathrm{~T}$ & $\mathrm{H}$ & $0.05(+/-0.002 \mathrm{SE}) \mathrm{H}^{1.06(+/-0.008 \mathrm{SE})}$ & 0.83 & 0.0000
\end{tabular}

Length weight relationships

\begin{tabular}{|c|c|c|c|}
\hline $\mathrm{W}_{\text {shell }}$ & $\mathrm{H}$ & $6.8110^{-5}\left(+/-2.7810^{-6} \mathrm{SE}\right) \mathrm{H}^{3.07(+/-0.01 \mathrm{SE})}$ & 0.97 \\
\hline $\mathrm{W}_{\text {tissue }}$ & $\mathrm{H}$ & $9.9410^{-6}\left(+/-4.5410^{-7} \mathrm{SE}\right) \mathrm{H}^{2.78(+/-0.01 \mathrm{SE})}$ & 0.97 \\
\hline
\end{tabular}

Organs sizes

$\begin{array}{lllll}\mathrm{W}_{\text {shell }} & \mathrm{W}_{\text {tissue }} & 23.67(+/-0.115 \mathrm{SE}) \mathrm{W}_{\text {tissue }} 1.08(+/-0.003 \mathrm{SE}) & 0.97 & 0.0000 \\ \mathrm{~W}_{\text {mu1 }} & \mathrm{W}_{\text {tissue }} & 0.326(+/-0.001 \mathrm{SE}) \mathrm{W}_{\text {tissue }} 1.10(+-0.002 \mathrm{SE}) & 0.99 & 0.0000 \\ \mathrm{~W}_{\text {mu2 }} & \mathrm{W}_{\text {tissue }} & 0.128(+/-0.001 \mathrm{SE}) \mathrm{W}_{\text {tissue }} 0.65(+/-0.004 \mathrm{SE}) & 0.89 & 0.0000 \\ \mathrm{~W}_{\text {gill }} & \mathrm{W}_{\text {tissue }} & 0.320(+/-0.001 \mathrm{SE}) \mathrm{W}_{\text {tissue }} 0.94(+-0.001 \mathrm{SE}) & 0.99 & 0.0000 \\ \mathrm{~W}_{\text {gonad }} & \mathrm{W}_{\text {tissue }} & 0.212(+/-0.001 \mathrm{SE}) \mathrm{W}_{\text {tissue }} 1.08(+/-0.004 \mathrm{SE}) & 0.96 & 0.0000\end{array}$

Shell increment 
Table 3 : Basic statistics of in situ growth in shell height, in heel depth, in shell weight and in tissue weight of the 3 age groups of pearl oysters.

\begin{tabular}{|c|c|c|c|c|c|c|c|c|c|c|c|c|}
\hline \multirow[b]{3}{*}{ Month } & \multicolumn{6}{|c|}{ Shell height (mm) } & \multicolumn{6}{|c|}{ Shell thickness (mm) } \\
\hline & \multicolumn{2}{|c|}{ Year class 1} & \multicolumn{2}{|c|}{ Year class 2} & \multicolumn{2}{|c|}{ Year class 3} & \multicolumn{2}{|c|}{ Year class 1} & \multicolumn{2}{|c|}{ Year class 2} & \multicolumn{2}{|c|}{ Year class 3} \\
\hline & Monthly mean & $\mathrm{SD}$ & Monthly mean & SD & Monthly mean & SD & Monthly mean & $\overline{\mathrm{SD}}$ & Monthly mean & $\overline{S D}$ & Monthly mean & $\overline{\mathrm{SD}}$ \\
\hline Mar. & 44.0 & 2.7 & 97.6 & 3.7 & 117.1 & 6.1 & 2.8 & 0.5 & 5.3 & 0.6 & 7.2 & $\overline{1.0}$ \\
\hline Apr. & 46.5 & 2.7 & 101.9 & 4.5 & 118.8 & 5.8 & 2.9 & 0.5 & 5.8 & 0.7 & 8.1 & 1.0 \\
\hline May & 48.2 & 3.0 & 102.7 & 5.6 & 119.4 & 5.9 & 2.5 & 0.5 & 5.4 & 0.6 & 7.5 & 0.8 \\
\hline June & 51.4 & 4.6 & 103.7 & 6.1 & 119.7 & 5.9 & 3.1 & 0.5 & 5.9 & 0.8 & 8.0 & 0.9 \\
\hline July & 56.4 & 4.6 & 104.9 & 5.5 & 121.6 & 6.8 & 3.2 & 0.6 & 6.0 & 0.8 & 7.9 & 1.0 \\
\hline Aug. & 61.2 & 5.9 & 107.4 & 5.7 & 123.1 & 7.9 & 3.6 & 0.5 & 6.4 & 0.8 & 8.2 & 1.0 \\
\hline Sep. & 62.4 & 6.2 & 109.5 & 6.0 & 126.1 & 7.2 & 4.0 & 0.6 & 6.7 & 0.8 & 8.5 & 1.0 \\
\hline Oct. & 63.2 & 7.1 & 111.7 & 6.2 & 125.4 & 7.4 & 4.1 & 0.5 & 7.0 & 0.9 & 8.4 & 1.0 \\
\hline Nov. & 68.0 & 6.1 & 110.7 & 7.1 & 126.1 & 7.6 & 4.6 & 0.6 & 7.1 & 0.8 & 8.7 & 0.9 \\
\hline Dec. & 70.3 & 5.6 & 108.9 & 4.2 & 126.4 & 4.6 & 4.5 & 0.5 & 7.0 & 0.6 & 8.6 & 0.7 \\
\hline Jan. & 76.5 & 7.1 & 109.0 & 7.6 & 126.4 & 6.5 & 4.6 & 0.6 & 6.5 & 1.0 & 8.2 & 1.2 \\
\hline Feb. & 77.5 & 7.9 & 112.4 & 5.6 & 127.1 & 8.1 & 4.9 & 0.6 & 6.5 & 0.9 & 8.4 & 1.3 \\
\hline Mar. & 76.8 & 10.2 & 113.1 & 7.1 & 125.2 & 8.4 & 5.1 & 0.6 & 7.2 & 0.9 & 8.9 & 1.2 \\
\hline (Apr.) & 76.5 & 10.5 & 113.3 & 6.7 & 126.8 & 8.2 & 5.2 & 0.7 & 7.1 & 0.9 & 8.8 & 1.3 \\
\hline \multirow{3}{*}{ Growth rate $\left(y^{-1}\right)$} & 32.7 & & 15.6 & & 8.1 & & 2.3 & & 1.9 & & 1.7 & \\
\hline & \multicolumn{6}{|c|}{ Shell dry weight (g) } & \multicolumn{6}{|c|}{ Tissue dry weight (g) } \\
\hline & \multicolumn{2}{|c|}{ Year class 1} & \multicolumn{2}{|c|}{ Year class 2} & \multicolumn{2}{|c|}{ Year class 3} & \multicolumn{2}{|c|}{ Year class 1} & \multicolumn{2}{|c|}{ Year class 2} & \multicolumn{2}{|c|}{ Year class 3} \\
\hline Month & Monthly mean & SD & Monthly mean & SD & Monthly mean & $\mathrm{SD}$ & Monthly mean & $\mathrm{SD}$ & Monthly mean & $\mathrm{SD}$ & Monthly mean & $\mathrm{nSD}$ \\
\hline Mar. & 8.9 & 1.7 & 81.0 & 10.7 & 158.5 & 21.8 & 0.5 & 0.1 & 2.9 & 0.4 & 5.8 & 0.9 \\
\hline Apr. & 9.8 & 2.1 & 88.8 & 15.0 & 164.3 & 18.0 & 0.5 & 0.1 & 3.3 & 0.6 & 6.0 & 0.8 \\
\hline May & 10.9 & 2.4 & 91.1 & 14.3 & 166.4 & 20.3 & 0.5 & 0.1 & 3.9 & 0.7 & 6.4 & 1.1 \\
\hline June & 11.9 & 2.9 & 97.9 & 16.4 & 168.9 & 20.5 & 0.6 & 0.1 & 4.2 & 0.8 & 6.1 & 1.1 \\
\hline July & 15.5 & 3.5 & 102.8 & 14.6 & 178.8 & 24.2 & 0.7 & 0.1 & 4.4 & 0.8 & 6.3 & 0.9 \\
\hline Aug. & 19.3 & 5.9 & 112.8 & 16.8 & 183.9 & 27.2 & 0.9 & 0.3 & 5.2 & 0.9 & 6.9 & 1.2 \\
\hline Sep. & 21.6 & 6.0 & 117.1 & 19.0 & 198.6 & 27.1 & 0.9 & 0.3 & 4.9 & 0.8 & 6.9 & 1.1 \\
\hline Oct. & 23.1 & 7.0 & 131.8 & 15.4 & 196.6 & 31.5 & 1.0 & 0.3 & 5.4 & 0.6 & 6.8 & 1.4 \\
\hline Nov. & 29.1 & 7.3 & 127.9 & 18.2 & 198.7 & 26.6 & 1.2 & 0.3 & 4.9 & 0.8 & 7.0 & 1.2 \\
\hline Dec. & 31.9 & 7.6 & 131.2 & 18.6 & 206.3 & 31.9 & 1.3 & 0.4 & 5.0 & 0.8 & 7.0 & 1.4 \\
\hline Jan. & 43.2 & 8.5 & 136.1 & 19.9 & 217.3 & 26.7 & 1.6 & 0.5 & 4.8 & 0.9 & 6.9 & 1.2 \\
\hline Feb. & 44.1 & 10.6 & 149.8 & 18.8 & 219.6 & 32.4 & 1.5 & 0.4 & 5.6 & 0.9 & 7.0 & 1.4 \\
\hline Mar. & 42.7 & 14.2 & 150.9 & 21.1 & 217.5 & 32.9 & 1.6 & 0.6 & 5.5 & 1.0 & 6.9 & 1.5 \\
\hline (Apr.) & 43.0 & 13.7 & 149.6 & 22.7 & 223.4 & 42.5 & 1.7 & 0.5 & 5.4 & 1.1 & 6.8 & 1.6 \\
\hline Growth rate $\left(\mathrm{y}^{-1}\right)$ & 33.8 & & 69.9 & & 59.0 & & 1.2 & & 2.7 & & 1.1 & \\
\hline
\end{tabular}


Table 4 : Daily growth rate for several parameters measured on P. margaritifera. This rates is obtained on the basis of the slope of the linear regression parameters vs time (in days).

\section{Daily growth rate}

\begin{tabular}{|c|c|c|c|c|c|c|c|}
\hline \multirow[b]{3}{*}{ Parame ters } & \multirow[b]{3}{*}{ Units } & \multirow{2}{*}{\multicolumn{2}{|c|}{ Year class 1}} & & & & \\
\hline & & & & \multicolumn{2}{|c|}{ Ye ar class 2} & \multicolumn{2}{|c|}{ Year class 3} \\
\hline & & Mean & $\mathrm{SE}$ & Mean & SE & Mean & $\mathrm{SE}$ \\
\hline $\mathbf{H}$ & $\left(\mathrm{mm}^{-1} \mathrm{~d}^{-1}\right)$ & 0.095 & 0.002 & 0.034 & 0.002 & 0.024 & 0.002 \\
\hline $\mathbf{T}$ & $\left(\mu m^{-1} d^{-1}\right)$ & 7.2 & 0.2 & 4.1 & 0.2 & 3.1 & 0.3 \\
\hline $\mathbf{W}_{\text {shell }}$ & $\left(\mathrm{mg}^{-1} \mathrm{~d}^{-1}\right)$ & 109.0 & 2.0 & 184.0 & 5.0 & 175.0 & 7.0 \\
\hline $\mathbf{W}_{\text {tissue }}$ & $\left(\mathrm{mg}^{-1} \mathrm{~d}^{-1}\right)$ & 3.68 & 0.09 & 5.30 & 0.23 & 2.51 & 0.31 \\
\hline
\end{tabular}


Table 5 :Value $( \pm$ SE) of the growth model parameters for separate organs and total soft tissue.

\begin{tabular}{|c|c|c|c|c|c|}
\hline & 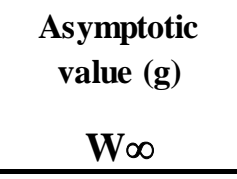 & $\begin{array}{c}\text { Growth rate } \\
\text { (g month }^{-1} \text { ) } \\
\text { k } \\
\end{array}$ & $\begin{array}{l}\text { Amplitude of } \\
\text { oscillation (g) } \\
\alpha \\
\end{array}$ & $\begin{array}{c}\text { Phase displacement } \\
\text { (month) } \\
\varphi \\
\end{array}$ & $\begin{array}{c}\begin{array}{c}\text { Adjustement } \\
\text { parameter }\end{array} \\
\text { a } \\
\end{array}$ \\
\hline Adductor muscle & $2.838+/-0.045$ & $0.196+/-0.010$ & $0.348+/-0.059$ & $1.399+/-0.290$ & $5.528+/-0.269$ \\
\hline Retractor muscle & $0.424+/-0.006$ & $0.248+/-0.023$ & $0.463+/-0.109$ & $1.394+/-0.377$ & $5.401+/-0.464$ \\
\hline Gill (+ Mantle) & $1.998+/-0.030$ & $0.194+/-0.010$ & $0.342+/-0.059$ & $1.585+/-0.305$ & $5.173+/-0.249$ \\
\hline Gonad (+ Digestive gland) & $1.395+/-0.297$ & $0.251+/-0.024$ & $0.765+/-0.145$ & $1.395+/-0.297$ & $6.658+/-0.605$ \\
\hline Total soft tissue & $6.904+/-0.095$ & $0.208+/-0.010$ & $0.435+/-0.061$ & $1.427+/-0.239$ & $5.578+/-0.261$ \\
\hline
\end{tabular}


Table 6 : Yearly increment in shell height $\left(\mathrm{mm} \mathrm{year}^{-1}\right)$ for several species and subspecies of Pinctada genus.

\begin{tabular}{|c|c|c|c|c|c|}
\hline \multirow[t]{2}{*}{ Species } & \multirow[t]{2}{*}{ Area } & \multicolumn{3}{|c|}{ Shell growth rate in height $\left(\mathrm{mm}\right.$ year $^{-1}$ ) } & \multirow[t]{2}{*}{ References } \\
\hline & & Year class 1 & Year class 2 & Year class 3 & \\
\hline \multirow{4}{*}{$\begin{array}{l}\text { P. margaritifera } \\
\text { var erythraensis }\end{array}$} & Dongonab Bay (Red Sea) & $\sim 50 \mathrm{~mm}$ & $\sim 40 \mathrm{~mm}$ & - & Nasr (1984) \\
\hline & Dongonab Bay (Red Sea) & & & & Elnaeim (1984) \\
\hline & Low density $\left(100 \mathrm{~m}^{-2}\right)$ & $\sim 52 \mathrm{~mm}$ & $\sim 28 \mathrm{~mm}$ & $\sim 23 \mathrm{~mm}$ & $"$ \\
\hline & High density $\left(600 \mathrm{~m}^{-2}\right)$ & $\sim 35 \mathrm{~mm}$ & - & - & $"$ \\
\hline \multirow{7}{*}{$\begin{array}{r}\text { P. margaritifera } \\
\text { var cumingi }\end{array}$} & Manihiki (Cook Islands) & $\sim 31 \mathrm{~mm}$ & $\sim 19 \mathrm{~mm}$ & - & Sims (1994) \\
\hline & Suwarrow (Cook Islands) & - & $\sim 14 \mathrm{~mm}$ & - & $"$ \\
\hline & Rakahanga (Cook Islands) & - & $\sim 16 \mathrm{~mm}$ & - & $"$ \\
\hline & Rangiroa (French Polynesia) & $\sim 37 \mathrm{~mm}$ & $\sim 25 \mathrm{~mm}$ & - & Leduc (1997) \\
\hline & Takapoto (French Polynesia) & $\sim 40 \mathrm{~mm}$ & $\sim 20 \mathrm{~mm}$ & $\sim 10 \mathrm{~mm}$ & Coeroli et al. (1984) \\
\hline & " & \multicolumn{2}{|c|}{$\sim 27 \mathrm{~mm}$} & - & Buestel et al. (1995) \\
\hline & $"$ & $\sim 33 \mathrm{~mm}$ & $\sim 16 \mathrm{~mm}$ & $\sim 8 \mathrm{~mm}$ & This study \\
\hline \multirow[t]{2}{*}{ P. mazatlanica } & Baja california (Mexico) & $\sim 25 \mathrm{~mm}$ & - & - & Saucedo and Monteforte (1997) \\
\hline & $"$ & $\sim 40 \mathrm{~mm}$ & - & - & Gaetan-Mondragon et al. (1993) \\
\hline \multirow[t]{2}{*}{ P. fucata vulgaris } & Gulf of Mannar (India) & - & $\sim 12 \mathrm{~mm}$ & - & Chellam (1978) \\
\hline & Tuticorin harbour (India) & $\sim 17 \mathrm{~mm}$ & $\sim 11 \mathrm{~mm}$ & - & $"$ \\
\hline P. fucata martensii & Ohmura Bay (Japan) & $\sim 12 \mathrm{~mm}$ & $\sim 15 \mathrm{~mm}$ & - & Wada (1991) \\
\hline
\end{tabular}


Table 7 : Value of Von Bertalanffy growth parameters for various species of bivalves according several climatic area. Stars $(*)$ indicates that parameters were re-calculated from the original data.

\begin{tabular}{|c|c|c|c|c|c|}
\hline \multirow[t]{2}{*}{ Climatic area } & \multirow[t]{2}{*}{ Species } & \multicolumn{3}{|c|}{ Shell growth in height } & \multirow[t]{2}{*}{ References } \\
\hline & & $\mathrm{H}_{\infty}$ & $\mathrm{k}\left(\mathrm{mm} \mathrm{y}^{-1}\right)$ & $\mathrm{t}_{0}(\mathrm{y})$ & \\
\hline \multirow{4}{*}{$\begin{array}{r}\text { Tropical (French polynesia } \\
\text { and Cook Islands) }\end{array}$} & P. margaritifera var & 181.7 & 0.35 & - & Sims (1994) \\
\hline & cumingi & $175.1-177.6$ & $0.37-0.42$ & $\sim 0$ & Leduc (1997) * \\
\hline & $"$ & 160.5 & 0.46 & 0.31 & This study \\
\hline & $"$ & 148.9 & 0.76 & 0.11 & Coeroli et al. (1984) * \\
\hline Desert (Red sea) & $\begin{array}{r}\text { P. margaritifera var } \\
\text { erythraensis }\end{array}$ & 125.5 & 1.24 & 0.50 & Elnaeim (1984) * \\
\hline Subtropical (California) & P. mazatlanica & 84.9 & 1.38 & 0.16 & Saucedo and Monteforte (1997) * \\
\hline \multirow[t]{2}{*}{ Tropical (India) } & P. fucata & $57.4-67.4$ & $1.06-1.15$ & - & Velayudhan et al. (1996) \\
\hline & $"$ & 79.3 & 0.90 & 0.04 & Chellam (1988) \\
\hline
\end{tabular}

* (re-) calculated from the original data given by the authors. 


\section{Figure captions}

Fig. 1 : Takapoto atoll and its lagoon (from SPOT picture). Cultivated oysters studied in this work were located at station 1 .

Fig. 2 : Temporal variations (from March 1997 to April 1998) of water parameters measured at station 1 (Depth $=7 \mathrm{~m}$ ) in Takapoto lagoon in the vicinity of the cultivated pearl oysters. $\mathbf{a}:$ Water temperature (Thick line) and Air temperature (Fine Line) ; b : Water salinity and oxygen concentration ; c : Particulate inorganic matter (PIM, \pm SE ; thick line) and wind speed (Fine line) ; d : Particulate organic matter (POM, \pm SE ; thick line) and wind speed (Fine line).

Fig. 3 : Pinctada margaritifera : growth and fitting of Von Bertalanffy (vB) and logistic (L) growth models for shell height (a), shell weight (b), tissue weight (c), muscles weight (d), gill weight (e) and gonad weight (f) according to age in days for the three age group ( $\bigcirc$ age group 1 ; $\bullet$ age group $2 ; \Delta$ age group 3 ). Some available data on age group $0(\mathbf{A})$ are also given. 
Figures

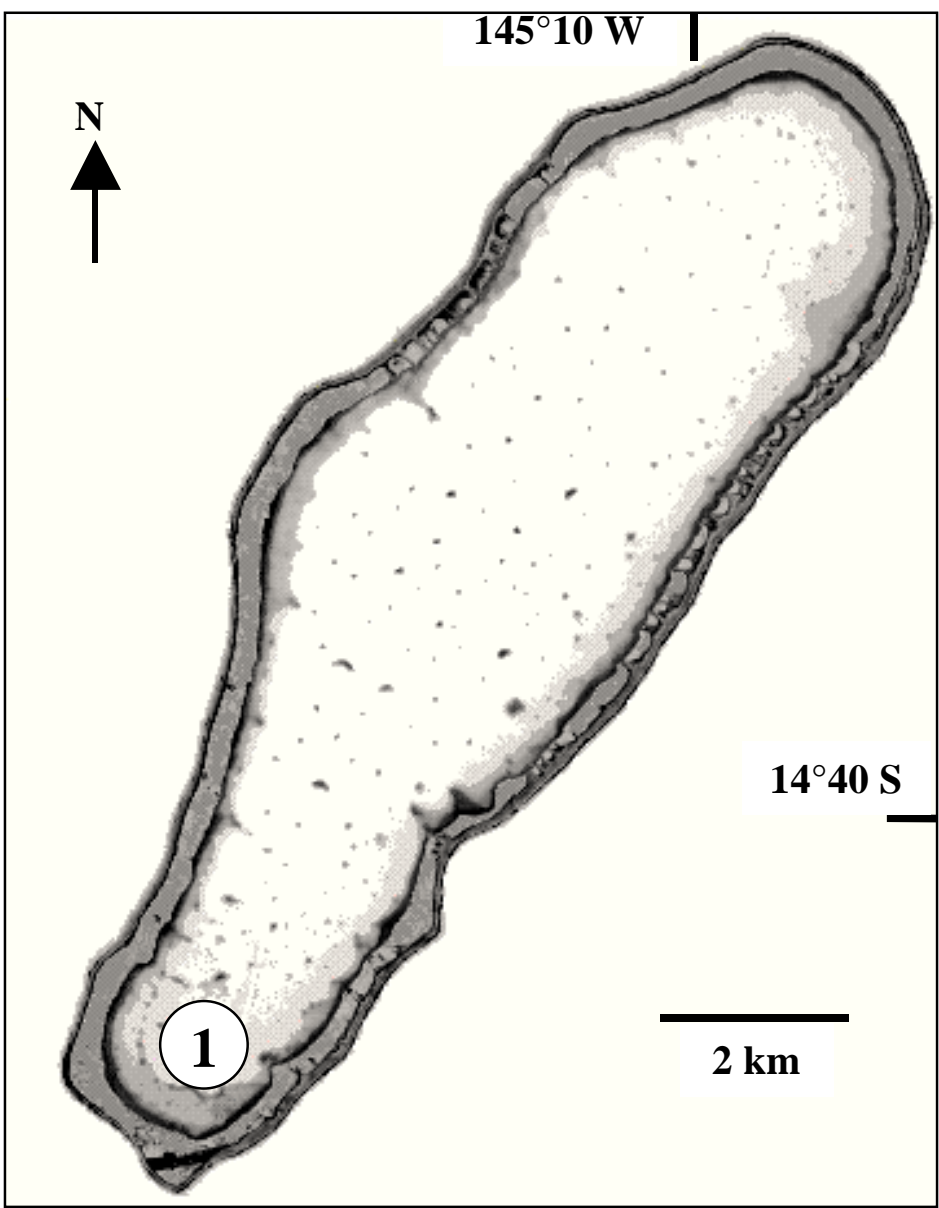

Figure 1 

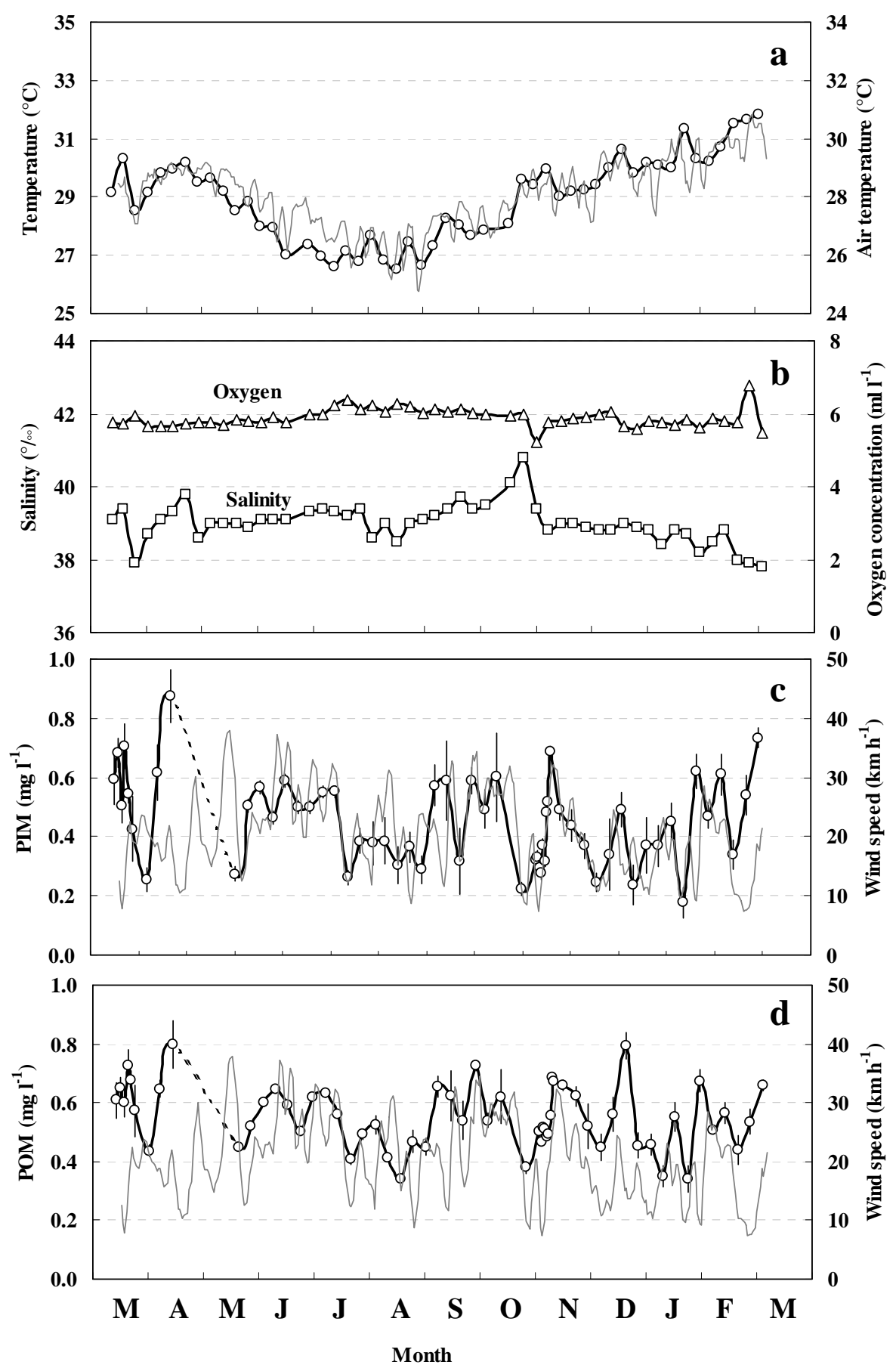

Figure 2 

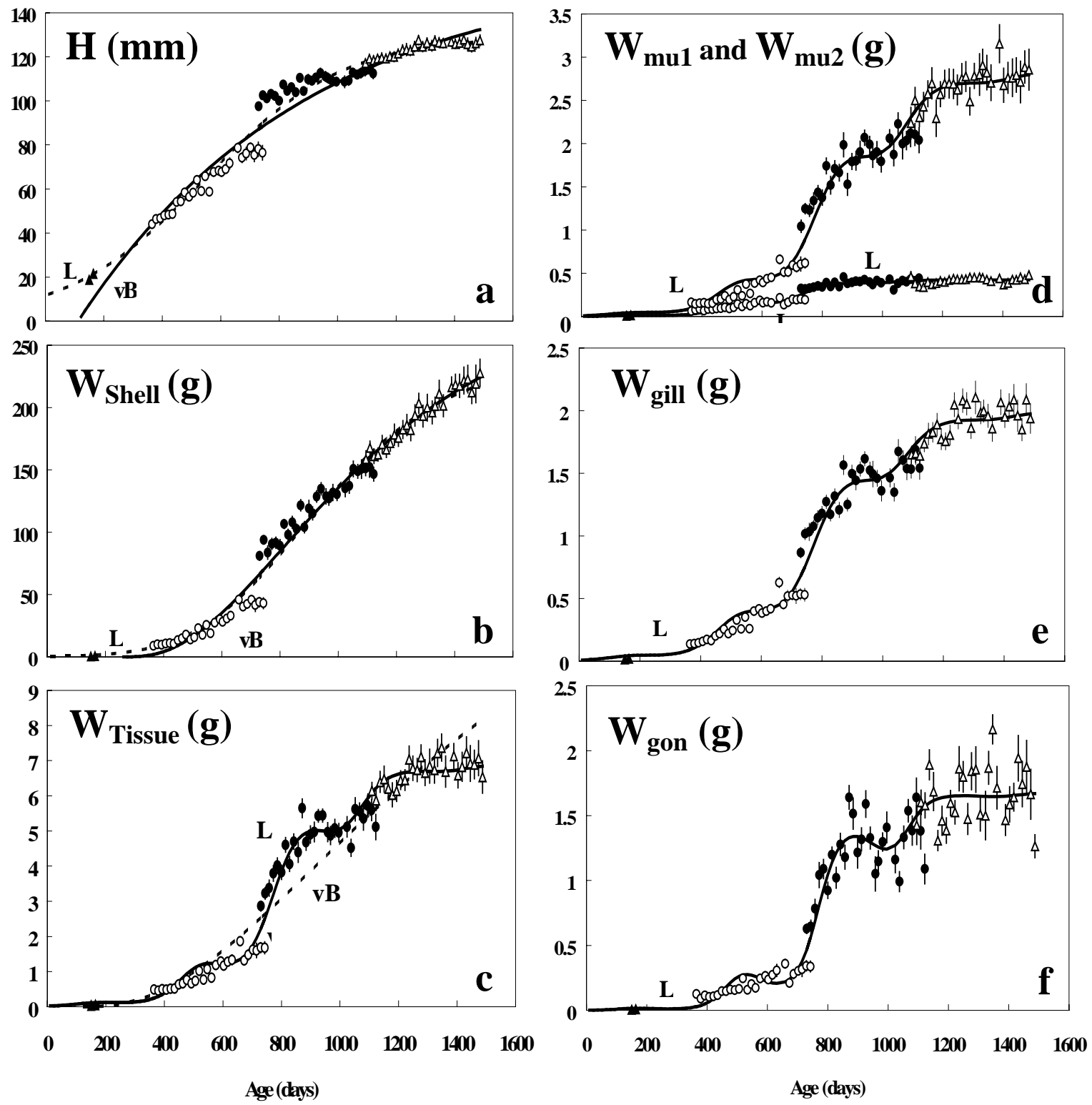

Figure 3 